\title{
EHMTI-0236. A qualitative study of the functional impact of symptoms on migraine patients
}

\author{
A Hareendran ${ }^{1 *}$, S Mannix ${ }^{2}$, A Skalicky $^{3}$, K Widnell $^{4}$, P Corey-Lisle ${ }^{5}$, S Sapra ${ }^{5}$ \\ From 4th European Headache and Migraine Trust International Congress: EHMTIC 2014 \\ Copenhagen, Denmark. 18-21 September 2014
}

\section{Introduction}

Migraines have significant impacts on patients, resulting in functional and quality of life impairments. There is limited qualitative data that describe the functional limitations related to episodic (EM) and chronic migraines (CM).

\section{Aims}

A qualitative study was conducted to understand migraine patients' experiences.

\section{Methods}

Five U.S. clinical sites recruited patients to complete interviews with trained researchers. Subjects provided IRB-approved informed consent and met the following eligibility criteria: $18-60$ years of age, and migraine history meeting IHS criteria. Interviews were conducted to elicit concepts that describe impacts on daily functioning. Transcripts were analyzed using qualitative methods.

\section{Results}

21 EM and $11 \mathrm{CM}$ patients were interviewed. Patient reported concepts were grouped into the following areas: physical function, everyday activities, social/relationship/ leisure activities, and emotional responses. Physical function impacts included difficulty with moving head and bending, needing to lie down, limited movement, avoiding bright lights and loud noises; everyday activities included household chores, running errands, activities requiring concentration, interacting with others, performing tasks related to work and/or school. Social/relationship/leisure activity and emotional impacts included inability to make plans, avoiding people, feeling frustrated, moody, and guilty. Physical function was described as the most immediate impact from symptoms, with emotional and social impacts occurring during and after symptoms.

Outcomes Research, Evidera, London, UK

Full list of author information is available at the end of the article

\section{Conclusion}

Functional impacts from migraine symptoms described by EM and CM patients can be grouped into 3 domains: physical, emotional, and social. Physical function limitations play a role in the immediate migraine experience. Emotional and social impacts are experienced during and after migraine episodes.

\section{Authors' details}

'Outcomes Research, Evidera, London, UK. ²Outcomes Research, Evidera, Bethesda, USA. ${ }^{3}$ Outcomes Research, Evidera, Seattle, USA. ${ }^{4}$ Global Development, Amgen Inc., Thousand Oaks, USA. ${ }^{5}$ Global Health Economics, Amgen Inc., Thousand Oaks, USA.

Published: 18 September 2014

doi:10.1186/1129-2377-15-S1-D53

Cite this article as: Hareendran et al:: EHMTI-0236. A qualitative study of the functional impact of symptoms on migraine patients. The Journal of Headache and Pain 2014 15(Suppl 1):D53.

\section{SpringerOpen ${ }^{\circ}$}

(c) 2014 Hareendran et al; licensee Springer. This is an Open Access article distributed under the terms of the Creative Commons Attribution License (http://creativecommons.org/licenses/by/2.0), which permits unrestricted use, distribution, and reproduction in any medium, provided the original work is properly cited.
Submit your manuscript to a SpringerOpen ${ }^{\circ}$ journal and benefit from:

- Convenient online submission

- Rigorous peer review

- Immediate publication on acceptance

- Open access: articles freely available online

- High visibility within the field

- Retaining the copyright to your article

Submit your next manuscript at $>$ springeropen.com 